\title{
Thinking about the Upcoming U.S. Elections
}

\author{
Jeffrey C. Isaac
}

"Why are you screaming? You have a microphone, it's amplified and when you shriek that way, it's such an unpleasant ..."

\section{- Geraldo Rivera}

"I think a lot of it with Hillary Clinton has to do with style and delivery, oddly enough. She shouts. There's something unrelaxed about the way she is communicating and I think that just jumps off ..."

-Bob Woodward

"What is likable about that? What is angry, bitter, screaming? I'm going to stop there."

- Sean Hannity

"She's aging, out of ideas, often shrill, apparently according to oral reports angry and clearly not inspiring."

-Sean Hannity

"Hillary Clinton's hair-raising tone on the campaign trail has garnered a lot of criticism, many saying she needs to cut it out and tone it down. But did you know that criticism is sexist? That's correct, sexist. That's according to Clinton surrogate Howard Dean ... That's rich, coming from the screamer."

$$
\text { —Kimberly Guilfoyle }
$$

"As Leon Wieseltier, the literary editor of The New Republic, once told me: 'She's never going to get out of our faces.... She's like some hellish housewife who has seen something that she really, really wants and won't stop nagging you about it until finally you say, fine, take it, be the damn president, just leave me alone.' That's why Hillary is laughing a lot now, big belly laughs, in response to tough questions or comments, to soften her image as she confidently knocks her male opponents out of the way. From nag to wag."

-Maureen Dowd

"I don't want to sound like the old ball-and-chain guy, but Hillary Clinton cannot be elected president because-am I wrong in feeling, am I the only one in America that feels this way? - that there's something about her vocal range. There's something about her voice that just drives me-it's not what she says, it's how she says it. She is like the stereotypicalexcuse the expression, but this is the way to-she's the stereotypical bitch, you know what I mean? She's that stereotypical, nagging, [unintelligible], you know what I mean? And she doesn't have to be saying — she could be saying happy things, but after four years, don't you think every man in America will go insane?"

—Glenn Beck
"Do you think Hillary looks presidential? I don't think so ... I'm not going to say it.... I refuse to say that I cannot stand her screaming into the microphone all the time... . because we're not allowed to say it, right?"

—Donald J. Trump

$\bigwedge$ fter months of vicious campaigning, Donald Trump eviscerated all sixteen of his original rivals for the Republican nomination ("Lyin' Ted," "Little Marco," "Ugly Carly," "Loser Jeb" and the rest), and immediately went on the attack against the presumptive Democratic nominee, Hillary Clinton, who was herself locked in a sometimes bitter race with Bernie Sanders for the nomination.

U.S. political science has much to contribute to the understanding of this electoral contest and its underlying dimensions, dynamics, and likely consequences. Readers of Monkey Cage, Vox, and numerous other blogs encounter illuminating versions of political science research on U.S. politics on a daily basis; commentaries by respected columnists such as E.J. Dionne, Jr. in the Washington Post and Thomas B. Edsall in the New York Times regularly feature political science discussions; and sometimes political science research makes its way even further to the top of political discussion, as with our September 2014 piece by Martin Gilens and Benjamin Page on "Testing Theories of American Politics," which went viral, and has also been cited frequently in connection with the Sanders campaign and its criticism of "oligarchy" (see especially Robert Reich, "The Most Pragmatic Way to Fix American Democracy: Elect Bernie Sanders"). This issue of Perspectives contains a variety of articles, essays, and reviews of direct relevance to the election and to the broader dynamics of U.S. politics. It also contains two terrific "Praxis" essays that reflect on the practical opportunities and challenges associated with direct involvement in political campaigns: Donald P. Green and Alan S. Gerber's "Voter Mobilization, Experimentation, and Translational Social Science" and Hahrie Han and Elizabeth McKenna's "Political Science, Field Campaigns, and Democratic Praxis."

It seems appropriate to lead our issue with Jennifer J. Jones's “Talk Like a Man: The Linguistic Styles of Hillary 
Clinton.” Jones draws on research in political psychology and political communication, and employs a quantitative textual analysis of almost 600 interview transcripts and candidate debates to analyze the shifts in the linguistic style of Clinton between 1992-the year in which she first served as First Lady—and 2013 - the year she began to make her move towards the 2016 Democratic presidential nomination. Jones finds that "Clinton's linguistic style grew increasingly masculine over time, as her involvement and power in the political world expanded." And she draws from this research a more general conclusion: "Women pursuing leadership positions are not simply halted by a glass ceiling, but by a labyrinth of obstacles they must navigate along the way. These obstacles, both implicit and overt, do not pose concrete barriers, but rather 'circuitous routes' toward attaining leadership positions. Expectations of leadership and institutional arrangements have implications for the types of individuals who run for public office as well as the self-presentational strategies that politically ambitious women use to advance through the labyrinth of leadership. To be successful, they must cultivate an appropriate and effective self-presentationone that reconciles symbolic attitudes toward gender with masculine prototypes of political leaders."

Jones helps us to understand why the rhetoric quoted at the very top of this Introduction has figured so prominently in the current election cycle. At the same time, as she makes clear, the gendered dynamics in play can also work in subtler ways. Janet Elise Johnson's "Fast-Tracked or Boxed In? Informal Politics, Gender, and Women's Representation in Putin's Russia," reminds us that these dynamics are rather universal, or at least in play in a range of places beyond the United States. Johnson argues that the inclusion of women into electoral politics is an important gain for gender equality but also a double-edged sword: "Women are being fast-tracked into politics informally, not just formally such as by party or legislative quotas. Yet these women are then boxed in by informal rules and by parallel institutions and posts, with virtually no opportunities to advocate for women's interests. Putin's regime has promoted women to be 'stand-ins' during times of crisis or change, 'loyalists' and 'showgirls' when the regime needs to showcase elections and representation, and 'cleaners' when the appearance of corruption threatens the regime. Even demonstrations of ultimate loyalty have not protected those women who once advocated for feminist policies ... These political processes, especially the loyalist box where there is the most evidence in this opaque political system, not only limit women-politicians' willingness and ability to substantively represent women, but incentivizes them to push for regressive policies. Instead of expanding women's substantive representation, the increase in women's descriptive representation has led to backlash, reinforcing male dominance and informal politics."
Donald Trump's derisive comment about Hillary Clinton's supposed playing of "the gender card" notwithstanding, this election-pitting a very visible and accomplished professional woman who is a liberal feminist against a man who epitomizes belligerent masculinity and has a demonstrated propensity to demean professional women in public (think Clinton, but also Megyn Kelly, Heidi Cruz, and Carly Fiorina)—vividly dramatizes the gendering of American politics.

Theda Skocpol and Alexander Hertel-Fernandez's "The Koch Network and Republican Party Extremism" centers on another theme vividly dramatized in this election, not in the opposition of Trump and Clinton but in the opposition of Sanders and Clinton: the role of private wealth, and of class and distributive conflict more generally, in politics. Skocpol and Hertel-Fernandez develop an "organizational" approach that in some ways parallels work published in Perspectives by Kay Lehman Schlozman, Sidney Verba, and Henry Brady, and by Jacob Hacker and Paul Pierson. They proceed from the observation that in recent years the Republican party has moved unremittingly rightward in ways that seem to counter median voter models. "Why has this happened?" they ask. "Standard wisdom blames current GOP extremism on unruly party base voters - on Tea Partiers, or Christian conservatives, or working-class nativists. In safely conservative legislative districts and presidential primaries dominated by base voters, GOP stances on social issues like abortion or immigration can be attributed to such pressures from below. But this explanation sheds little light on accelerating GOP economic extremism." In order to explain this development, they draw upon data and findings from a new research project on "The Shifting U.S. Political Terrain" that focuses on organizations rather than simply on mass publics or aggregates of wealthy donors. While they do not deny the importance of wealthy donors such as the Koch brothers themselves, their article maps the vast organizational network associated with Koch Industries and the Koch brothers, which includes the Freedom Partners Chamber of Commerce, the Koch seminars, the Libre Initiative, Themis/i360, Aegis Strategic, the Cato Institute, the Mercatus Center at George Mason University, and the American Legislative Exchange Council (See Hertel-Fernandez's article on ALEC in our September 2014 issue). And it centers on a case study of Americans for Prosperity, a centrally-directed yet federated organization that promotes "a broad pro-free-market agenda with a highly disciplined focus on economic and political issues." They claim that "in some ways, AFP's connection to the GOP is similar to the 'anchoring' relationship that the labor movement used to enjoy with Democrats ... On webpages, in statements to the media, in lobbying efforts, and at public protests, messages from national and state AFP operatives focus relentlessly on promoting tax cuts, blocking and eliminating business 
regulations, opposing the landmark health reform law passed in 2010, pushing for reductions in funding of (and, where possible, the privatization) public education and social-welfare programs, and opposing state-level environmental initiatives and any from the U.S. Environmental Protection Agency." And they argue that "because of its massive scale, tight integration, ramified organizational reach, and close intertwining with the GOP at all levels, the Koch network exerts a strong gravitational pull on many Republican candidates and officeholders, re-setting the range of economic issues and policy alternatives to which they are responsive." (On the theme of ideological and partisan polarization, see also this issue's Critical Dialogue between Hans Noel, author of Political Ideologies and Political Parties in America, and Russell Muirhead, author of The Promise of Party in a Polarized Age. And on the broader theme of political mobilization, see Daniel Carpenter's article "Recruitment by Petition: American Antislavery, French Protestantism, English Suppression.")

Jacob Hacker's "America's Welfare Parastate" nicely complements Skocpol and Fernandez's article, reviewing a growing literature on the distinctive features of the American welfare state, which is comparatively stingy in its social spending but comparatively lavish in its provision of "social benefits delivered or subsidized through the tax code." "The result," he argues, "is a framework of social protection that is not just maddeningly complex but also unevenly perceived. Big expenditure programs like Social Security and Medicare are hard to miss. But the rest of the framework - the assortment of tax breaks and regulated private benefits and third-party providers-lies mostly beneath the surface of public consciousness. It is, as Suzanne Mettler puts it ... a 'submerged state." Hacker notes that this framework has long contributed to a public myopia about social spending, but that "the rise of Donald Trump and the insurgent campaign of Sanders in 2016 both suggest that public pressures for social protection are building.... Perhaps more important, race and racism continue to greatly complicate the task of increasing support for public protections. Among many downscale white voters, public programs are seen as the province of blacks, Hispanics, and undocumented immigrants (even though virtually every social program is majority white, Hispanics are generally underrepresented among program beneficiaries, and undocumented immigrants are often excluded altogether). Donald Trump's presidency augers a nativist backlash at least as much as it suggests a latent coalition for robust measures to aid displaced workers." Our Review section contains two other features dealing with distributional politics: a Critical Dialogue between James Druckman and Lawrence Jacobs, authors of Who Governs? Presidents, Public Opinion, and Manipulation and Daniel M. Butler, author of Representing the Advantaged: How Politicians Reinforce Inequality, and an Undisciplined review essay by Sanford Schram on Matthew Desmond's ethnography Evicted: Poverty and Profit in the American City. And John Boswell's "Deliberating Downstream: Countering Democratic Distortions in the Policy Process" discusses the resistance of policy processes to political change even in the instances when this change is legislated and seems to reflect the mobilization of rational opinion formation.

On the topic of "nativist backlash," our issue contains a very important piece of public opinion research, Morris Levy, Matthew Wright and Jack Citrin's "Mass Opinion and Immigration Policy in the United States." The piece proceeds from a situation that has become central to the current presidential contest: "Hundreds of bills in the last twenty-five years have sought to augment, scale back, or rebalance an admissions regime that, at present, allocates roughly one million green cards each year to relatives of U.S. citizens and legal permanent residents (about twothirds of visas), skilled workers (15 percent), and refugees (15 percent). Acrimonious debates have repeatedly played out at all levels of government over the fate of an estimated 12 million illegal immigrants, many of whom arrived in the United States as children, have family ties here, or are so integrated into American society that returning home is unthinkable to them. Should they be deported as 'lawbreakers?' Legalized as aspirants to the American dream? Tolerated in a policy of 'salutary neglect?'” Levy, Wright, and Citrin argue that the scholarly conventional wisdom is that this patchwork of policies is unpopular, and that it persists, rather than giving way to a more restrictive policy, because of the influence of "elites and organized lobbies" that support a liberal and relatively permissive regimea view that parallels the arguments made by advocates of immigration restriction. They subject this perspective to empirical test, and report the results of a survey experiment that shows that "Americans' abstract desire to reduce immigration co-exists with broad-based support for the pillars of the expansionary status quo-family reunification, recruitment of skilled labor, and admitting refugees. This contradictory mix of opinions arises because the actual contours of visa preferences evoke humanitarian and sociotropic considerations that compete with the exclusionary impulses tapped by more abstract poll questions. The point here is not that the public is more 'proimmigrant' than generally believed or that it will support large-scale immigration irrespective of the political context, but that failing to take stock of divergence between abstract policy aims and specific means of achieving them makes one ignore the permissive consensus supporting the status quo." Their piece contains implications for public policy analysis and for how we understand the ways that public opinion is currently being mobilized, and it warrants careful attention. In the current U.S. election cycle, immigration policy has become a hot-button issue in connection both with Donald Trump's call for the building of "a wall" at the U.S.-Mexican border and 
with his call for a ban on the entry of Muslims into the United States. But the issue is very live throughout the world, especially in the light of the massive waves of refugees and migrants who are crossing the Mediterranean in flight from war in Syria, Libya, Iraq, Afghanistan, Eritrea, Nigeria, and elsewhere. This issue contains three Critical Dialogues dealing with the topic, between Marisa Abrajano and Zoltan Hajnal's White Backlash: Immigration, Race, and American Politics and Sarah Wallace Goodman's Immigration and Membership Politics in Western Europe; Leila Kawar's, Contesting Immigration Policy in Court: Legal Activism and Its Radiating Effects in the United States and France and Stuart Chinn, Recalibrating Reform: The Limits of Political Change; and Ayten Gundogdu, Rightlessness in an Age of Rights: Hannah Arendt and the Contemporary Struggles of Migrants, and Ben Herzog, Revoking Citizenship: Expatriation in America from the Colonial Era to the War on Terror.

Race also plays an obvious role in the current election cycle. The substantial weakness of the Republican Party in attracting support from African-Americans and Latinos has been widely noted in the press, and Black Lives Matter activists have been very visible both in demonstrating against the Trump campaign and in pressing the Sanders and Clinton campaigns to be more responsive to links between race, criminalization, and state-sanctioned violence. These themes feature prominently in our Critical Dialogue between Michael Javen Fortner, author of Black Silent Majority: The Rockefeller Drug Laws and the Politics of Punishment and Daniel Kato, author of Liberalizing Lynching: Building a New Radicalized State. They also are the focus of a symposium we have organized on recent controversies surrounding the racial legacies of Woodrow Wilson, at Princeton and beyond. My symposium charge sums up the issues:

Woodrow Wilson is the only American political scientist to have served as President of the United States. In the time between his political science Ph.D. (from Johns Hopkins, in 1886) and his tenure as U.S. president (1913-1921), he also served as president of Princeton University (1902-1910) and president of the American Political Science Association (1909-1910). Wilson is one of the most revered figures in American political thought and in American political science. The Woodrow Wilson Award is perhaps APSA's most distinguished award, given annually for the best book on government, politics, or international affairs published in the previous year, and sponsored by the Woodrow Wilson Foundation at Princeton University.

Woodrow Wilson has also recently become the subject of controversy, on the campus of Princeton University, and in the political culture more generally, in connection with racist statements that he made and the segregationist practices of his administration. A group of Princeton students associated with the "Black Lives Matter" movement has demanded that Wilson's name be removed from two campus buildings, one of which is the famous Woodrow Wilson School of Public and International Affairs (see Martha A. Sandweiss, "Woodrow Wilson, Princeton, and the Complex Landscape of Race," http://www.thenation.com/article/woodrow-wilson-princeton-andthe-complex-landscape-of-race/). Many others have resisted this idea, noting that Wilson is indeed an important figure in the history of twentieth-century liberalism and Progressivism in the United States.

A number of colleagues have contacted me suggesting that Perspectives ought to organize a symposium on the Wilson controversy. Although we do not regularly organize symposia around current events, given the valence of the controversy and its connection to issues we have featured in our journal (see especially the September 2015 issue on "The American Politics of Policing and Incarceration)," and given Wilson's importance in the history of our discipline, we have decided to make an exception in this case. We have thus invited a wide range of colleagues whose views on this issue will interest our readers to comment on this controversy.

Our symposium features current APSA President Jennifer Hochschild, APSA Past President Dianne Pinderhughes, National Conference of Black Political Scientists (NCBPS) President Todd Shaw, NCBPS President-elect Shayla Nunnally, Eldon Eisenach, Desmond Jagmohan, Dara Strolovitch and Chaya Crowder, and David Wilson. The issue also includes a review essay by Desmond King, "Illiberalism Unbound: Rethinking America's Progressive Legacy," that addresses similar themes. (In our forthcoming December issue we will include a symposium on Robert Vitalis's White World Order, Black Power Politics: The Birth of American International Relations, and also an Undisciplined review essay by Vitalis on Aldon Morris's The Scholar Denied: $W$. E.B. Dubois and the Birth of Modern Sociology).

The legal status accorded members of the GLBT community is another lightening rod of partisan controversy in the current electoral cycle. While the Supreme Court's 2015 decision in Obergefell v. Hodges declared that the right to marry is guaranteed to all individuals, including same-sex couples, according to the Fourteenth Amendment, Republican resistance to the enforcement of this right has been practiced in many states on grounds of "state's rights." Legal and political contests over the issue of GLBT rights have also figured prominently in the news in connection with legislation passed in North Carolina and in Mississippi, and that have been debated in Indiana, Arkansas, and elsewhere, that allows discrimination against GLBT individuals on grounds of "religious liberty." These controversies have been further accentuated by the May 13, 2016, directive issued by the Obama Administration's Department of Education and Department of Justice, which construed Title IX of the 1972 Education Amendments as prohibiting "discrimination based on a student's sexual identity, including discrimination based on a student's transgender status," and requiring that public schools receiving Title IX funding be in compliance with this "significant guidance." Our symposium on Stephen Macedo's Just Married: Same-Sex Couples, Monogamy, 
and the Future of Marriage, featuring commentaries by Scott Barclay, Joe Fishel, and Jyl Josephson, speaks directly to these issues.

Perhaps the most surprising development in the 2016 presidential contest has been the extraordinary success of Bernie Sanders, an avowed "democratic socialist" and a septuagenarian who came of age in the 1960's and who first entered politics as a New Left student activist in Chicago involved in civil rights and anti-Vietnam War organizing. Such involvements were also foundational for many of those who have shaped the current discipline of political science in the United States over the past three decades. The recent publication of a new edition of "The Port Huron Statement," the 1962 manifesto of Students for a Democratic Society, seemed like an opportune moment to invite a wide range of important disciplinary figures who experienced the New Left as graduate students or young professors to comment on how the Statement, and its theme of "participatory democracy," shaped their thinking as political scientists. While many of the original list of invitees were unable to participate, we are pleased that those who were able to contribute include a stellar cast of commentators: Mark Blitz,
William Connolly, Peter Gourevitch, Phil Green, Frances Fox Piven, Wilbur Rich, Sid Tarrow, Molly Shanley and Martha Ackelsberg, and Nick Xenos. That generation of scholars was largely in rebellion against prophecies of an "end of ideology" that by the late sixties had proven horribly wrong. We live, and work, at a time in which another declaration of "the end to history" has proven wrong. The acrimony, and the corroding fault lines, of the current moment in U.S. electoral politics has its parallels in too many other places the world over. Recent challenges to liberal democracy in Hungary, Poland, but also Austria, France, and even Great Britain, currently in the midst of a bitter "Brexit" controversy, further intensify a sense of abiding concern, if not crisis. At the same time, electoral processes carry on. The tension between the relative normalcy of electoral politics and the lingering anxiety, fear, and sense of grievance among large segments of the populations of many of the most important nation-states in the world is palpable. In the coming years we will face many challenges, and be forced to answer many questions. We political scientists have our work cut out for us. 


\section{Statement of Mission and Procedures}

Perspectives on Politics seeks to provide a space for broad and synthetic discussion within the political science profession and between the profession and the broader scholarly and reading publics. Such discussion necessarily draws on and contributes to the scholarship published in the more specialized journals that dominate our discipline. At the same time, Perspectives seeks to promote a complementary form of broad public discussion and synergistic understanding within the profession that isessential toadvancing scholarship and promoting academic community.

Perspectives seeks to nurture a political science public sphere, publicizing important scholarly topics, ideas, and innovations, linking scholarly authors and readers, and promoting broad reflexive discussion among political scientists about the work that we do and why this work matters.

Perspectives publishes work in a number of formats that mirror the ways that political scientists actually write:

Research articles: As a top-tier journal of political science, Perspectives accepts scholarly research article submissions and publishes the very best submissions that make it through our double-blind system of peer review and revision. The only thing that differentiates Perspectives research articles from other peer-reviewed articles at top journals is that we focus our attention only on work that in some way bridges subfield and methodological divides, and tries to address a broad readership of political scientists about matters of consequence. This typically means that the excellent articles we publish have been extensively revised in sustained dialogue with the editor-me-to address not simply questions of scholarship but questions of intellectual breadth and readability.

"Reflections" are more reflexive, provocative, or programmatic essays that address important political science questions in interesting ways but are not necessarily as systematic and focused as research articles. These essays often originate as research article submissions, though sometimes they derive from proposals developed in consultation with the editor in chief. Unlike research articles, these essays are not evaluated according to a strict, doubleblind peer review process. But they are typically vetted informally with editorial board members or other colleagues, and they are always subjected to critical assessment and careful line-editing by the editor and editorial staff.

Scholarly symposia, critical book dialogues, book review essays, and conventional book reviews are developed and commissioned by the editor in chief, based on authorial queries and ideas, editorial board suggestions, and staff conversations.

Everything published in Perspectives is carefully vetted and edited. Given our distinctive mission, we work hard to use our range of formats to organize interesting conversations about important issues and events, and to call attention to certain broad themes beyond our profession's normal subfield categories.

For further details on writing formats and submission guidelines, see our website at http://www.apsanet.org/ perspectives/ 